\section{Phenolic Content and Antioxidant Capacity of Pawpaw Fruit (Asimina triloba L.) at Different Ripening Stages}

\author{
Hideka Kobayashi ${ }^{1}$, Changzheng Wang ${ }^{2,4}$, and Kirk W. Pomper ${ }^{3}$ \\ Human Nutrition Program, Atwood Research Facility, Kentucky State \\ University, Frankfort, KY 40601
}

\begin{abstract}
Pawpaw [Asimina triloba (L.) Dunal], a native species of the eastern United States, bears the largest edible fruit of all indigenous trees. Chemoprotective properties of fruits have been partly attributed to phenolics such as gallic acid and chlorogenic acid, and the phenolic content generally correlates with antioxidant capacity for various kinds of fruits. Despite many reports of commonly available fruits, little information is available on phenolic content or antioxidant capacity for currently underused fruits. The objectives of this study were to determine the phenolic content (PC) and antioxidant capacity (AC) in fruit of two pawpaw cultivars at different stages of ripening. Sample extraction of pawpaw was achieved by adding acetone $(2 \mathrm{~mL} / 1 \mathrm{~g}$ of sample) to the pulp of 'PA-Golden (\#1)' and advanced selection 1-23, and then vortexing (30 s) and sonicating (15 min.) the sample and solvent before centrifuging it $(15 \mathrm{~min})$ twice at $2987 \mathrm{~g}$. FolinCiocalteu assay and ferric reducing/antioxidant power assay were used for the estimation of $\mathrm{PC}$ and $\mathrm{AC}$, respectively. $\mathrm{PC}$ and $\mathrm{AC}$ tended to decrease with ripening of fruit. The highest AC was found in the semiripe 'PA-Golden (\#1)' puree (22.06 $\mu \mathrm{mol} \mathrm{TE} / \mathrm{g}$ fresh weight), whereas the puree of ripe fruit contained the lowest AC $(17.04 \mu \mathrm{mol} \mathrm{TE} / \mathrm{g}$ fresh weight), about a $23 \%$ decrease. In contrast, the greatest $\mathrm{PC}$ and $\mathrm{AC}$ were observed in intermediate fruits for 1-23. A positive correlation was found between $\mathrm{PC}$ and $\mathrm{AC}$ of fruit of 'PA-Golden (\#1)' $(r=0.62)$ and 1-23 $(r=0.82)$. These results suggest that phenolic components of pawpaw pulp have a major effect on $\mathrm{AC}$, as reported for other fruits and vegetables. The relatively high AC found in pawpaw pulp may motivate more healthconscientious people to consume pawpaw fruit. The diversity in $\mathrm{PC}$ and AC between pawpaw cultivars emphasizes the need for additional screening to identify cultivars with high $\mathrm{AC}$ and health-promoting potential.
\end{abstract}

Recently, much attention has been paid to understanding the roles of fruits and vegetables in the promotion of human health and prevention of chronic diseases. Epidemiological studies have repeatedly shown the apparent association between high fruit intake and the lower incidence of chronic diseases (Ness and Powles, 1997; New et al., 2000). The chemoprotective properties of fruits have been partly attributed to phenolics such as gallic acid and chlorogenic acid, and the phenolic content (PC) generally correlates with antioxidant capacity (AC) for various types of fruits (Olsson et al., 2004; Sun et al., 2002). Phenolic antioxidants can scavenge free radical species, inhibit free radical formation, and prevent damage to cellular com-

Received for publication 13 June 2007. Accepted for publication 13 Aug. 2007.

This research was supported by U.S. Dept. of Agriculture, Cooperative State Research, Education, and Extension Service Agreement no. KYX-2003-03971 with Kentucky State University. ${ }^{1}$ Co-Investigator of Human Nutrition.

${ }^{2}$ Principal Investigator of Human Nutrition

${ }^{3}$ Principal Investigator of Horticulture and Curator, USDA National Clonal Germplasm Repository for Asimina species.

${ }^{4}$ To whom reprint requests should be addressed; e-mail changzheng.wang@kysu.edu ponents, and subsequent cellular damage or death (Sun et al., 2002).

Despite many reports of commonly available fruits such as blueberry and apple on their PC and AC, little information is available for currently underused fruits. These underused fruits may contain a significant amount of phytochemicals or even unique compounds that are health promoting. Their AC may be comparable or even superior to that of the more extensively studied fruits. For example, a study conducted at the USDA Human Nutrition Center found that blueberry had the greatest $\mathrm{AC}$ of all 40 fresh fruits and vegetables examined (Cao et al., 1996). The strong AC and other evidence of health-promoting properties have helped blueberry become a popular commercial fruit crop (Butkus and Pliszka, 1993, Haddad et al., 2001; McAnulty et al., 2004; Rossi et al., 2003; Schmidt et al., 2004; Weiguang et al., 2006)

Pawpaw [Asimina triloba (L.) Dunal] is a small tree found in the temperate woodlands of the Eastern United States that bears the largest edible fruit of all native species (Kral, 1960; Pomper and Layne, 2005). Efforts to popularize pawpaw started in the early part of the last century through domestication and development of superior cultivars (Peterson, 2003). The interest in pawpaw waned over the years, possibly because of perishability
(Archbold and Pomper, 2003; Popenoe, 1916, 1917) and the increasing popularity of other domestic fruit crops such as blueberry (Pomper and Layne, 2005). However, pawpaw is enjoying resurgence in popularity as a niche crop. The pawpaw fruit has a flavor that resembles a combination of banana (Musa $\times$ paradisiaca L.), mango (Mangifera indica L.), and pineapple [Ananas comosus (L.) Merr.], and is a rich source of nutritive components (Pomper and Layne, 2005). Pawpaw fruit is generally similar to banana in its nutritive components, including carbohydrate, dietary fiber, and protein, and it has markedly higher amounts of vitamin $\mathrm{C}$ and minerals (Pomper and Layne, 2005). However, PC, AC, and the potential healthpromoting properties of pawpaw remain unscrutinized. Changes in $\mathrm{PC}$ and $\mathrm{AC}$ of fruits are often associated with ripening of fruits (Amiot et al., 1995, Burda et al., 1990; Lima et al., 2005). It is not known whether $\mathrm{AC}$ in pawpaw fruit varies by cultivar or ripening stage. The objectives of this study were to determine the $\mathrm{PC}$ and $\mathrm{AC}$ in the fruit of two pawpaw cultivars at different stages of ripening.

Pawpaw fruit from 'PA-Golden (\#1)' and the advanced selection 1-23 were harvested from the Research and Demonstration Farm of Kentucky State University in Frankfort, Kentucky. 'PA-Golden (\#1)' is a commercially available second-generation seedling from the G.A. Zimmerman collection. This cultivar has a slight color break or yellowing of the skin that can be observed when the fruit starts to ripen. The advanced selection 1-23 is an open-pollinated seedling of 'Taylor' (a commercially available pawpaw variety), and was developed by the Pawpaw Foundation in cooperation with the University of Maryland and Kentucky State University (Pomper et al., 2003). This selection has potential for commercialization because of its desirable color and taste (Duffrin and Pomper, 2006).

Stages of ripening of pawpaw fruits were defined as unripe (no softening), semiripe (few soft spots), and ripe (uniform softening). The pulp of five fruits from the advanced selection 1-23 at each ripening stage was harvested on 27 Aug. 2004. Five 'PA-Golden (\#1)' fruits at each ripening stage (total of 10) were harvested on 27 Aug. 2004 and again on 1 Sept. 2004. Internal fruit firmness was measured by the penetration force of the fruit surface using a Texture Analyser (QTS 25, Farnell, Hertfordshire, UK) with a 5-mmdiameter flat stainless probe at a speed of $10 \mathrm{~mm} \cdot \mathrm{min}^{-1}$. The force needed to penetrate the fruit to $3 \mathrm{~mm}$ was used as the indicator of firmness. After the pulp was separated from the skin and seeds, soluble solid content (SSC) of the fruit pulp was measured with a refractometer (Carl Zeiss, Jena, Germany).

Pawpaw pulp from each fruit was individually placed in a 7-oz plastic bag (Whirl-Pak, NASCO, Fort Atkinson, WI), and was subsequently stored at $-20{ }^{\circ} \mathrm{C}$. The sample was thoroughly thawed before being dispensed into $50-\mathrm{mL}$ plastic centrifuge tubes, and the 
weight of both the tube and the samples was recorded. Acetone was added at $2 \mathrm{~mL} / \mathrm{g}$ of sample. After the addition of acetone, samples were thawed in the solvent to prevent oxidation, vortexed for $30 \mathrm{~s}$, and then sonicated for 15 min. The samples were then centrifuged twice at $2980 \mathrm{~g}$ to obtain supernatant for analysis of $\mathrm{PC}$ and $\mathrm{AC}$.

All chemical reagents were purchased from Sigma (St. Louis, MO) unless otherwise mentioned. The PC was quantified by a modified protocol of Singleton and Rossi (1965) for 96-well plates (Dicko et al., 2005). Absorbance of the mixture was measured at $760 \mathrm{~nm}$ with a microplate reader (VERSAmax, Molecular Devices, Sunnyvale, CA). After initial evaluation of the reaction kinetics for up to $150 \mathrm{~min}$, the absorbance reading at 90 min was selected to determine the total PC, expressed in miliigrams of gallic acid equivalent per 100 grams of fresh weight (mg GAE/100 g fresh weight).

The AC of pawpaw extract was quantified by ferric reducing/antioxidant power (FRAP) assay (Benzie and Strain, 1999), adapted for 96-well plates (Firuzi et al., 2005). Working FRAP solution was freshly made by mixing $15 \mathrm{~mL}$ of acetate buffer ( $300 \mathrm{~mm})$ and $1.5 \mathrm{~mL}$ of 2,4,6-tripyridyl-s-triazine $(10 \mathrm{~mm})$ and $\mathrm{FeCl}_{3} \cdot 6 \mathrm{H}_{2} \mathrm{O}$ solution. Acetate buffer and FRAP solution were warmed to $37^{\circ} \mathrm{C}$ before adding to the well of the plate. Absorbance of the mixture was measured at $595 \mathrm{~nm}$ with the aforementioned microplate reader at $37{ }^{\circ} \mathrm{C}$. The antioxidant power was expressed in micromoles of Trolox (a water-soluble ana$\log$ of vitamin $\mathrm{E}$ ) equivalent per gram of fresh weight ( $\mu \mathrm{M}$ TE/g fresh weight). The absorbance readings at $60 \mathrm{~min}$ were used after preliminary experiments.

Each pulp sample was analyzed three times. The results were analyzed using twoway nlysis of variance followed by the least significant difference test for mean comparison. Regression analysis was used to examine the relationship between $\mathrm{PC}$ and $\mathrm{AC}$ for both genotypes. All statistical analyses were performed using the statistical software package PC-SAS, version 8E (SAS Institute, Cary, NC).

Overall, 'PA-Golden (\#1)' had significantly greater hardness, lower SSC, and higher PC and AC than the advanced selection 1-23 (Table 1). The SSC tended to increase with ripening more for 'PA-Golden (\#1)' than for the advanced selection 1-23. This was in agreement with others, who observed that SSC gradually increased during ripening in various types of fruits, including muskmelon/muskmelon (Corzo and Gomez, 2004; Villanueva et al., 2004), cherry (Yoon et al., 2006), mango (Jha et al., 2006), and nectarine (Aubert et al., 2003). The increase in SSC may be from water loss during ripening (Corzo and Gomez, 2004) or degradation of starch and subsequent conversion into sucrose, glucose, fructose, and galactose (Villanueva et al., 2004). Considering that no change in water content was observed in pawpaw pulp (data not shown), starch catabolism and subsequent conversion into mono- saccharide and disaccharides are the possible cause of the increase in SSC in pawpaw pulp.

$\mathrm{PC}$ and $\mathrm{AC}$ tended to decrease with ripening of fruit. The highest $\mathrm{AC}$ was found in the semiripe 'PA-Golden (\#1)' puree $(22.06 \mu \mathrm{mol}$
$\mathrm{TE} / \mathrm{g}$ fresh weight), whereas the puree of ripe fruit contained the lowest AC $(17.04 \mu \mathrm{mol}$ $\mathrm{TE} / \mathrm{g}$ fresh weight), about a $22.8 \%$ decrease. In contrast, the greatest $\mathrm{PC}$ and $\mathrm{AC}$ were observed in intermediate fruit for 1-23. Of all

Table 1. Effect of maturity status on physiochemical characteristics of two pawpaw clones, 'PA-Golden $(\# 1)^{\prime}(\mathrm{n}=10)$ and the PawPaw Foundation advanced selection 1-23 $(\mathrm{n}=5)$ harvested in 2004.

\begin{tabular}{lcccc}
\hline $\begin{array}{l}\text { Clone and fruit } \\
\text { maturity }\end{array}$ & $\begin{array}{c}\text { Penetration } \\
\text { force }(\mathrm{N})\end{array}$ & $\begin{array}{c}\text { Soluble solid } \\
\text { content }\left({ }^{\circ} \text { Brix }\right)\end{array}$ & $\begin{array}{c}\text { Phenolic content } \\
(\mathrm{mg} \mathrm{GAE} / 100 \mathrm{~g} \mathrm{FW})\end{array}$ & $\begin{array}{c}\text { Antioxidant capacity } \\
(\mu \mathrm{mol} \text { TE/g FW })\end{array}$ \\
$\begin{array}{l}\text { 'PA-Golden (\#1) } \\
\text { Unripe }\end{array}$ & $12.31 \mathrm{a}^{\mathrm{z}}$ & $15.10 \mathrm{~b}$ & $123.06 \mathrm{a}$ & $21.43 \mathrm{a}$ \\
$\quad \begin{array}{l}\text { Semiripe } \\
\text { Ripe }\end{array}$ & $1.04 \mathrm{~b}$ & $15.78 \mathrm{ab}$ & $106.22 \mathrm{~b}$ & $22.06 \mathrm{a}$ \\
1-23 & $0.72 \mathrm{~b}$ & $16.73 \mathrm{a}$ & $98.42 \mathrm{~b}$ & $17.04 \mathrm{~b}$ \\
Unripe & $1.63 \mathrm{a}$ & $18.25 \mathrm{a}$ & $71.41 \mathrm{a}$ & $16.94 \mathrm{~b}$ \\
Semiripe & $0.65 \mathrm{~b}$ & $18.55 \mathrm{a}$ & $76.23 \mathrm{a}$ & $19.88 \mathrm{a}$ \\
Ripe & $0.44 \mathrm{c}$ & $18.65 \mathrm{a}$ & $64.11 \mathrm{~b}$ & $15.57 \mathrm{~b}$ \\
\hline
\end{tabular}

${ }^{\mathrm{z}}$ Means followed by the same letter are not significantly different within the same column $(P<0.05)$.
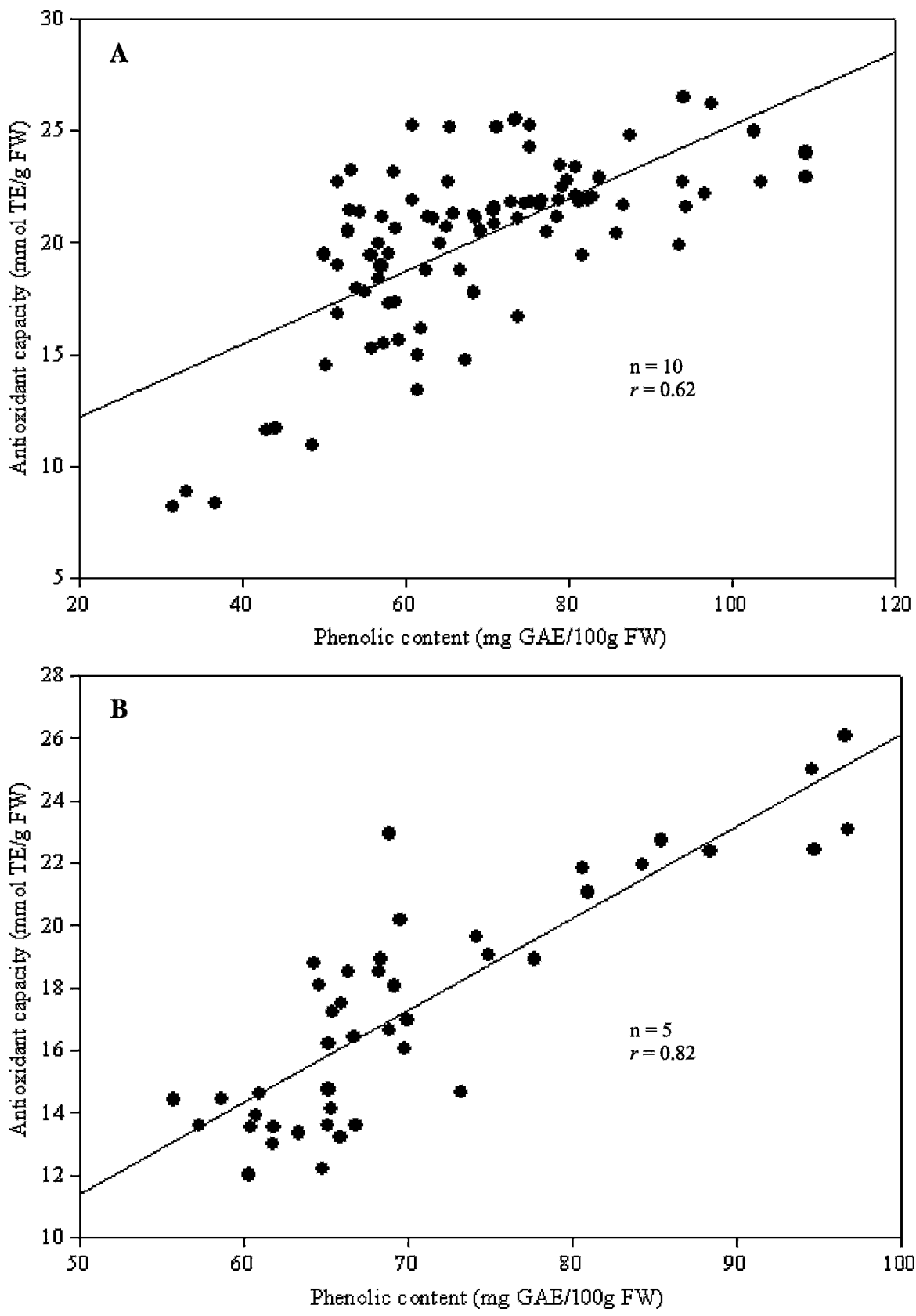

Fig. 1. Correlations between phenolic content and antioxidant capacity of puree of 'PA-Golden (\#1)' (A) and $1-23(\mathrm{~B})$. 
correlation coefficients obtained, only PC and AC showed a high correlation for both cultivars (Fig. 1). These results suggest that phenolic components of pawpaw pulp have a major effect on $\mathrm{AC}$, as reported for other fruits and vegetables (Wu et al., 2004).

Compared with other common fruits, $\mathrm{PC}$ and $\mathrm{AC}$ of pawpaw were equivalent or even superior in some cases. Although PC of pawpaw fruit examined in this study was lower than that of cranberry, apple, red grape, and strawberry, it is comparable or superior to other fruits such as lemon, peach, orange, banana, pear, pineapple, and grapefruit, as reported by Sun et al. (2002). Blueberry is well known for its $\mathrm{AC}$, but it can vary depending on cultivars, storage duration (Connor et al., 2002), and place of production (Taruscio et al, 2004). The PC and AC of pawpaw fruit are comparable to those of at least some blueberry cultivars.

In conclusion, the relatively high AC found in pawpaw pulp may motivate more health-conscientious people to consume pawpaw fruit. The diversity in PC and AC between pawpaw cultivars emphasizes the need for additional screening to identify cultivars with high AC and health-promoting potential.

\section{Literature Cited}

Amiot, M.J., M. Tacchini, S.Y. Aubert, and W. Oleszek. 1995. Influence of cultivar, maturity stage, and storage conditions on phenolic composition and enzymatic browning of pear fruits. J. Agr. Food Chem. 43:1132-1137.

Archbold, D.D., R. Koslanund, and K.W. Pomper. 2003. Ripening and postharvest storage of pawpaw. HortTechnology 13:439-441.

Aubert, C., C. Ambid, R. Baumes, and Z. Günata. 2003. Investigation of bound aroma constituents of yellow-fleshed nectarines (Prunus persica L. cv. Springbright). Changes in bound aroma profile during maturation. J. Agr. Food Chem. 51:6280-6286.

Benzie, I.F.F. and J.J. Strain. 1999. Ferric reducing/ antioxidant power assay: Direct measure of total antioxidant activity of biological fluids and modified version for simultaneous measurement of total antioxidant power and ascorbic acid concentration. Methods Enzymol. 299:15-27.

Burda, S., W. Oleszek, and C.Y. Lee. 1990. Phenolic compounds and their changes in apples during maturation and cold storage. J. Agr. Food Chem. 38:945-948.

Butkus, V. and K. Pliszka. 1993. The highbush blueberry: A new cultivated species. Acta Hort. 346:81-86.
Cao, G., E. Sofic, and R.L. Prior. 1996. Antioxidant capacity of tea and common vegetables. J. Agr. Food Chem. 44:3426-3431.

Connor, A.M., J.J. Luby, J.F. Hancock, S. Berkheimer, and E.J. Hanson. 2002. Changes in fruit antioxidant activity among blueberry. J. Agr. Food Chem. 50:893-898.

Corzo, O. and E.R. Gomez. 2004. Optimization of osmotic dehydration of cantaloupe using desired function methodology. J. Food Eng. 64:213-219.

Dicko, M.H., H. Gruppen, A.S. Traore, W.H. van Berkel, and A.G.J. Voragen. 2005. Evaluation of the effect of germination on phenolic compounds and antioxidant activities in sorghum varieties. J. Agr. Food Chem. 53:25812588.

Duffrin, M.W. and K.W. Pomper. 2006. Development of flavor descriptors for pawpaw fruit puree: A step toward the establishment of native fruit industry. Fam. Consum. Sci. Res. J. 35:118-130.

Firuzi, O., A. Lacanna, R. Petrucci, G. Marrosu, and L. Saso. 2005. Evaluation of the antioxidant activity of flavonoids by "ferric reducing antioxidant power" assay and cyclic voltammetry. Biochim. Biophys. Acta 1721:174 184.

Haddad, P.S., M. Depot, A. Settaf, and Y. Cherrah. 2001. Use of antidiabetic plants in Morocco and Quebec. Diabetes Care 24:609.

Jha, S.N., A.R.P. Kingsly, and S. Chopra. 2006 Physical and mechanical properties of mango during growth and storage for determination of maturity. J. Food Eng. 72:73-76.

Kral, R. 1960. A revision of Asimina and Deeringothamnus (Annonaceae). Brittonia 12: 233-278.

Lima, V.L.A.G., E.A. Mélo, M.I.S. Maciel, F.L. Prazeres, R.S. Musser, and D.E.S. Lima. 2005. Total phenolic and carotenoid contents in acerola genotypes harvested at three ripening stages. Food Chem. 90:565-568.

McAnulty, S.R., L.S. McAnulty, D.C. Nieman, C.L. Dumke, J.D. Morrow, A.C. Utter, D.A Henson, W.R. Proulx, and G.L. George. 2004. Consumption of blueberry polyphenols reduces exercise-induced oxidative stress compared to vitamin C. Nutr. Res. 24:209-221.

Ness, A.R. and J.W. Powles. 1997. Fruit and vegetables, cardiovascular disease: A review. Int. J. Epidemiol. 26:1-13.

New, S.A., S.P. Robins, M.K. Campbell, J.C. Martin, M.J. Garton, C. Bolton-Smith, D.A. Grubb, S.J. Lee, and D.M. Reid. 2000. Dietary influences on bone mass and bone metabolism: Further evidence of a positive link between fruit and vegetable consumption and bone health. Am. J. Clin. Nutr. 71:142-151.

Olsson, M.E., K.-E. Gustavsson, S. Andersson, Å. Nilsson, and R.-D. Duan. 2004. Inhibition of cancer cell proliferation in vitro by fruit and berry extracts and correlations with antioxidant levels. J. Agr. Food Chem. 52:7264-7271.

Peterson, R.N. 2003. Pawpaw variety development: A history and future prospects. HortTechnology 13:449-454.

Popenoe, W. (ed.). 1916. Where are the best pawpaws? J. Hered. 7:291-296.

Popenoe, W. (ed.). 1917. The best pawpaws. J. Hered 8:21-23.

Pomper, K.W., D.R. Layne, R.N. Peterson, and D. Wolfe. 2003. The Pawpaw Regional Variety Trial: Background and early data. HortTechnology 13:412-417.

Pomper, K.W. and D.R. Layne. 2005. The North American Pawpaw. Botany and Horticulture. Hortic. Rev. 31:351-384.

Rossi, M., E. Giussani, R. Morelli, R. Lo Scalzo, R.C. Nani, and D. Torreggiani. 2003. Effect of fruit blanching on phenolics and radical scavenging activity of highbush blueberry juice. Food Res. Intern. 36:99-105.

Schmidt, B.M., A.B. Howell, B. McEniry, C.T. Knight, D. Seigler, J.W. Erdman, and M.A. Lila. 2004. Effective separation of potent antiproliferation and antiadhesion components from wild blueberry (Vaccinium angustifolium Ait.) fruits. J. Agr. Food Chem. 52:64336442.

Singleton, V.L. and J.A. Rossi. 1965. Colorimetry of total phenolics with phosphomolybdic-phosphotungstic acid reagents. Amer. J. Enol. Vitic. 16:144-153.

Sun, J., Y.-F. Chu, X. Wu, and R.H. Liu. 2002. Antioxidant and antiproliferative activities of common fruits. J. Agr. Food Chem. 50:74497454.

Taruscio, T.G., D.L. Barney, and J. Exon. 2004. Content and profile of flavanoid and phenolic acid compounds in conjunction with the antioxidant capacity variety of Northwest Vaccinium berries. J. Agr. Food Chem. 52:31693176.

Villanueva, M.J., M.D. Tenorio, M.A. Esteban, and M.C. Mendoza. 2004. Compositional changes during ripening of two cultivars of muskmelon fruits. Food Chem. 87:179-185.

Weiguang, Y., C.C. Akoh, J. Fischer, and G. Krewer. 2006. Effects of phenolic compounds in blueberries and muscadine grapes on HepG2 cell viability and apoptosis. Food Res. Intern. 39:628-638.

Wu, X., G.R. Beecher, J.M. Holden, D.B. Haytowitz, S.E. Gebhardt, and R.L. Prior. 2004. Lipophilic and hydrophilic antioxidant capacities of foods in the United States. J. Agr. Food Chem. 52:4026-4037.

Yoon, K.Y., E.E. Woodams, and Y.D. Hang. 2006 Relationship of acid phosphatase activity and Brix/acid ratio in cherries. Lebensm. Wiss. Technol. 39:316-320. 